Hikmah Rahmasari
Universitas Islam Negeri
Raden Mas Said, Surakarta

hikmahr54@gmail.com

\section{Penggunaan Media Youtube sebagai Solusi Media Pembelajaran Bahasa Arab di Masa Pandemi}

\author{
DOI: 10.18196/mht.v3i1.11362
}

\begin{abstract}
The objective of this research is to see how far Youtube has become the right Arabic learning media solution for Distant Learning System (PJJ) during the pandemic. This research used the descriptive qualitative method while the data collection technique used the random probability sampling; the data analysis method used the data reduction method; data presentation; and finally, conclusion. The research subjects were the eleventh grade students at SMAIT Al Huda (Al Huda Islamic High School), Wonogiri. The result of this research shows that Youtube is the right solution for Arabic learning during the pandemic, with a percentage of $80.4 \%$ of the students belong to the category strongly agree. Hence, it shows positive results.
\end{abstract}

Keywords: Youtube; Learning Media; Arabic Language; Pandemic Period

\begin{abstract}
Abstrak
Penelitian ini bertujuan untuk melihat sejauh mana Youtube sebagai solusi media pembelajaran bahasa Arab yang tepat di masa pandemi dengan sistem Pembelajaran Jarak Jauh (PJJ). Penelitian ini menggunakan metode deskriptif kualitatif dengan teknik pengumpulan data menggunakan random probability sampling, adapun analisis data pada penelitian ini dengan data reduksi, penyajian data, dan kesimpulan. Subjek Penelitian pada peserta didik kelas XI di SMAIT Al Huda Wonogiri. Dengan hasil penelitian menunjukkan bahwa media Youtube adalah solusi yang tepat untuk media pembelajaran bahasa Arab di masa pandemi, dengan persentase hasil survei $(80,4 \%)$ peserta didik sangat setuju, sehingga menunjukkan hasil yang positif.
\end{abstract}

Kata kunci: Youtube; Media Pembelajaran; Bahasa Arab; Masa Pandemi 


\section{PENDAHULUAN}

Pandemi Covid-19 menjadi polemik bagi seluruh tatanan kehidupan manusia baik nasional maupun internasional, berdampak besar pada berbagai sektor. Tidak hanya sektor kesehatan dan ekonomi, melainkan juga pada sektor pendidikan yang sangat terdampak. Dunia pendidikan mengalami perubahan yang luar biasa drastis, setelah adanya pandemi ini. Seakan dunia pendidikan dipaksa bertransformasi untuk beradaptasi dengan cepat, guna melakukan suatu keadaan yang dulunya belum pernah dilakukan. Misalnya pembelajaran dari rumah melalui sistem Pembelajaran Jarak Jauh (PJJ), pendidik dan peserta didik dipaksa untuk mampu melalui situasi ini. Usah silih berganti untuk membuat program pendidikan yang kompatibel baik dari Pemerintah pusat, daerah, dan para pendidik secara individual atau kelompok Musyawarah Guru Mata Pelajaran (MGMP). Bersama-sama menyelamatkan anak bangsa, semangat belajar tidak boleh putus walau di masa pandemi.

Masalah pun tiada henti dalam pelaksanaan Pembelajaran Jarak Jauh ini, melihat belum meratanya fasilitas dan kemampuan peserta didik dalam mengakses internet dan kepemilikan gawai. Kementerian Pendidikan dan Kebudayaan (Kemdikbud) mengungkapkan terdapat 12 ribu sekolah yang memiliki keterbatasan akses internet yaitu pada daerah 3T (Terluar, Tertinggal, dan Terdepan). Terdapat 48 sekolah yang memiliki koneksi jaringan yang buruk di berbagai penjuru daerah Indonesia. Begitupun hasil survei yang dilakukan Direktorat Jenderal Pendidik dan Tenaga Kependidikan Kementerian Pendidikan dan Kebudayaan RI bersama Tim Pendidikan Wahana Visi Indonesia mengenai pendapat para pendidik dalam proses kegiatan pembelajaran di masa pandemi ini, dengan hasil 95\% sepakat Pembelajaran Jarak Jauh atau kombinasi, 38\% memilih melakukan pembelajaran sepenuhnya daring, 12\% Pembelajaran Jarak Jauh secara luring menjadi pilihan, dan hanya 5\% memilih tatap muka pembelajaran secara langsung. Melihat begitu banyaknya polemik di saat pandemi ini menuntut para pendidik untuk menciptakan, mengembangkan media pembelajaran hingga peserta didik tetap nyaman belajar walau di rumah.

Dengan hasil penelitian tersebut pembelajaran terkini menggunakan sistem Pembelajaran Jarak Jauh atau kombinasi. Adapun terbitnya Surat Edaran No. 15 
Tahun 2020 mengenai Pedoman Penyelenggaraan Belajar Dari Rumah Dalam Masa Darurat Penyebaran Covid-19, Chatarina Muliana Girsang memaparkan bahwasanya terbitnya surat edaran ini untuk memperkuat Surat Edaran Mendikbud No. 4 Tahun 2020. Belajar dari Rumah (BDR) menggunakan metode dan media pelaksanaan dengan sistem PJJ yang tergolong menjadi dua pendekatan yaitu PJJ dalam jaringan (daring) dan luar jaringan (luring), dengan kata lain menggunakan sistem kombinasi antara daring dan luring.

Dalam pembelajaran belajar dari rumah bukan tanpa halangan, terlebih dalam mata pelajaran bahasa Arab. Mata pelajaran ini menjadi tantangan tersendiri dalam kegiatan pembelajarannya, karena pada dasarnya bahasa Arab bukanlah bahasa ibu yang sudah dipelajari sejak dini oleh peserta didik. Sehingga bukan pelajaran yang mudah jika belajar secara mandiri di rumah. Namun di era yang semakin maju ini dengan banyaknya sarana untuk melaksanakan kegiatan pembelajaran mampu membantu peserta didik dalam proses pembelajarannya di rumah, diantaranya dengan media pembelajaran menggunakan Youtube sebagai solusi pembelajaran di masa pandemi ini. Mata pelajaran bahasa Arab ini juga diajarkan di SMAIT Al Huda Wonogiri, dan Youtube. Adalah salah satu media pembelajaran yang digunakan.

Media pembelajaran yang menggunakan teknologi salah satunya yaitu Youtube. Youtube Menjadi salah satu sarana yang mudah untuk pembelajaran yang dibentuk dan dibuat untuk kebutuhan dan penyempurnaan dalam pembelajaran yaitu dengan media berbasis Youtube (Seminar and Etnomatnesia 2014, 810). Adapun video pada Youtube bisa digolongkan menjadi dua jenis. Menurut hasil penelitian pada mata pelajaran bahasa Inggris, pertama adalah video-video berupa ceramah atau kuliah sebagai sumber belajar. Kedua adalah video-video wawancara. Dalam penelitian ini menunjukkan bahwa terdapat persepsi yang positif tentang penggunaan Youtube di kelas bahasa Inggris (Lestari 2013, 607). Begitu pula dalam pembelajaran Pendidikan Agama Islam menggunakan Youtube sebagai media pembelajaran yang menunjukan hasil yang positif yaitu mempermudah belajar, mengembangkan keterampilan TIK, meningkatkan profesionalitas pendidik dalam penggunaan media Youtube, dan membentuk sekolah menjadi lembaga yang memiliki pembelajaran kreatif dan dinamis (Baihaqi, Mufarroha, and Imani 2020, 74). 
Seperti halnya, pendapat lain dari hasil penelitian sebelumnya. Mengenai kekurangan dan kelebihan media Youtube sebagai media pembelajaran dalam bahasa asing yang dalam penelitian tersebut dalam bahasa Perancis. Diantara kelebihannya yaitu: (1) Mendapatkan informasi terkait materi pelajaran, (2) Memfasilitasi untuk berdiskusi dengan mereview video terkait, (3) Memudahkan peserta didik dalam belajar bahasa asing dengan melihat video terkait, (4) Pembelajaran mudah diingat. Sedangkan kekurangan dari media ini yaitu: (1) Jaringan yang terkadang lambat, (2) resolusi gambar yang buruk jika video di download dengan kapasitas rendah, (3) Pembelajaran terkesan membosankan apabila video pembelajaran kurang menarik dan terkesan monoton, (4) Jika terkendala jaringan atau internet, pendidik harus mengunduh video pembelajaran sebelum mengajar (Wulandari 2017, 3). Pendapat lain mengenai Youtube sebagai solusi alternatif media pembelajaran dan sebagai usaha untuk menaikkan kualitas pengajaran pendidik di masa pandemi, pendidik sebagai sumber belajar adalah bagian terpenting dalam penyampaian materi sehingga harus memiliki banyak cara untuk mencapai kualitas pengajaran yang mahir.

SMAIT Al Huda Wonogiri adalah sekolah dibawah naungan Jaringan Sekolah Islam Terpadu (JSIT). Berdiri sejak tahun 2015, beralamat di Bulusulur Kabupaten Wonogiri. SMAIT Al Huda Wonogiri memiliki konsep boarding schoo/yang mewajibkan seluruh peserta didik tinggal di asrama dengan program kepesantrenan yang terintegrasi dengan pondok. Di masa pandemi ini sebagian besar peserta didik belajar dari rumah menggunakan sistem PJJ sesuai dengan aturan Pemerintah yang berlaku pada saat ini. Berbagai media pembelajaran digunakan saat pembelajaran jarak jauh salah satunya yaitu media Youtube pada mata pelajaran bahasa Arab. Dimana pendidik menstimulasi peserta didik dari video pembelajaran yang berkaitan dengan 4 keterampilan berbahasa, sehingga meningkatkan semangat dan motivasi peserta didik saat belajar dari rumah sehingga Youtube sebagai solusi media pembelajaran di masa pandemi.

\section{LANDASAN TEORI}

\section{Media Pembelajaran}

Bahasa asal dari kata media adalah bahasa Latin, memiliki bentuk jamak "medium". Secara harfiah memiliki arti perantara atau pengantar pesan dari pengirim 
ke penerima pesan. Arief Sadiman, dkk mengemukakan arti media adalah pengirim pesan yang disampaikan oleh pengirim kepada penerima pesan sehingga berperan sebagai perantara atau pengantar (Sadiman dkk 1996, 7). Dari pengertian ini media adalah alat sebagai pengantar pesan, pesan dalam pembelajaran yang dimaksud adalah materi pelajaran dari sebuah mata pelajaran. Bagian integral dari strategi dan teori belajar dalam proses pembelajaran adalah media. Tanpa sebuah media, pembelajaran tidak akan pernah terjadi secara optimal. Sebaliknya jika pemilihan media pembelajaran itu baik dan tepat, maka akan menghasilkan pembelajaran yang maksimal. Media apapun yang akan digunakan, sasaran utamanya adalah memudahkan belajar, bukan untuk kemudahan belajar.

Pembelajaran bahasa memiliki konsep dasar diantaranya adalah (1) terdapat instrumen fisik, (2) Memiliki fungsi sebagai jembatan diantara pesan-pesan atau materi pembelajaran bahasa, (3) pendidik merancang rencana pembelajaran dalam proses pembelajarannya seperti merancang strategi, metode, dan pendekatan (4) memiliki sumber belajar, serta (5) terdapat kesinambungan antara pengajar, pembelajar, materi, dengan tujuan pembelajaran (Dewi and Budiana 2018, 55). Tujuan pembelajaran bahasa Arab adalah untuk membentuk kemampuan peserta didik pada keterampilan mendengar, berbicara, membaca dan menulis menggunakan bahasa Arab dalam kehidupan sehari-hari serta mampu memahami kitab suci Al 'Qur'an dan As Sunnah dengan pemahaman yang baik dan benar.

Menurut Sanaky (2015) dalam Harsanto 2017, tujuan media pembelajaran antara lain: mengantarkan materi pembelajaran dari pengajar kepada peserta didik dengan cara yang mudah serta efisien, menjaga konsentrasi peserta didik, serta terdapat peningkatan efektivitas dan kualitas pembelajaran (Harsanto 2017, 21). Adapun menurut Sudjana dan Rivai (2010) dalam Dewi dan Budiman 2018, media pembelajaran bertujuan untuk meminimalisir penyampaian materi pembelajaran secara verbal, membantu peserta didik lebih mudah paham terhadap materi pembelajaran terkait dengan jelas dengan kehidupan nyata (Dewi and Budiana 2018).

\section{Youtube sebagai Media Pembelajaran Bahasa Arab}

Rapidbe (2012) memaparkan akibat kegiatan pembelajaran terhadap peningkatan kemampuan peserta didik, seperti berikut: $10 \%$ yang dibaca dari peserta didik, 20\% dari yang didengar, 30\% dari yang dilihat, 50\% dari yang dilihat dan 
didengar, $70 \%$ dari yang ditulis dan dikatakan, dan $90 \%$ dari yang dikatakan dan dilakukan (Susanto and Akmal 2019, 15). Dari presentasi tersebut terdapat perbedaan yang diperoleh dari berbagai indra seperti yang sudah disebutkan. Maka media pembelajaran dapat dipersiapkan dengan konsep yang mengarah untuk optimalisasi pemanfaatan media pembelajaran yang sesuai dengan kegiatan membaca, mendengar, melihat, menulis, mengucapkan, dan melaksanakan. Dan artinya perlu adanya pengembangan dalam media pembelajaran sebagai upaya untuk peningkatan pengetahuan, pemahaman, dan daya kreativitas peserta didik dalam memperoleh ilmu pengetahuan, media pembelajaran yang dapat dikembangkan misalnya media audio, visual, video, dan media interaktif. Youtube pun termasuk dalam media berbentuk audio visual.

Media sosial Youtube adalah menjadi pilihan utama untuk berbagi video. Untuk keperluan pembelajaran, Youtube sangat relevan untuk digunakan sebagai media berbagi video pengajaran maupun praktik atau pemberian contoh kepada peserta didik (Harsanto 2017). Dengan kata lain Youtube dapat menjadi sumber belajar peserta didik dan juga sebagai media pembelajaran. Dalam konteks pembelajaran bahasa Arab tentulah peserta didik akan sangat terbantu jika materi mata pelajaran bahasa Arab divisualisasikan menggunakan video. Dan akan memacu kreativitas pendidik untuk terus berkarya membuat video pembelajaran yang inovatif sehingga meningkatkan motivasi peserta didik agar selalu belajar dalam kondisi apapun, terutama di masa pandemi ini yang sistem pembelajaran menggunakan pembelajaran jarak jauh.

\section{Pembelajaran pada Masa Pandemi}

Proses pendidikan di situasi seperti ini harus ditangani dengan tepat, tidak hanya pemerintah melainkan seluruh stakeholder harus saling membantu dalam penanganan memutuskan tali rantai Covid-19. Adapun perihal yang harus dilakukan yakni: (1) Pemerintah, sesuai dengan Instruksi Presiden No. 4 tahun 2020 tentang refocusing kegiatan, relokasi anggaran, serta pengadaan barang dan jasa dalam rangka percepatan penanganan Covid-19 harus segera dilaksanakan, (2) Orang tua, adanya peran orang tua di masa pandemi Covid-19 baik dukungan secara material dan moral, (3) Pendidik, berusaha pembelajaran berjalan efektif. Tidak hanya mentransfer ilmu melainkan ing ngarso sung tuladha ing madya mangun karsa, tut 
wuri handayani, (4) dan yang terakhir yaitu sekolah, harus mampu memfasilitasi perubahan apapun yang menyangkut pendidikan peserta didiknya.

Pembelajaran dalam kondisi seperti ini menggunakan sistem Pembelajaran Jarak Jauh atau dengan kata lain pembelajaran kombinasi, perpaduan antara daring dan luring. Penelitian yang dilakukan oleh Oliver dan Trigwell (2005) dalam Mariani 2020, meneliti makna dan maksud dengan sistem campuran atau blended learning. Dengan hasil penelitian bahwa campuran (mixed) dalam blended learning meliputi: (1) Campuran antara e-learning dan pembelajaran tradisional, (2) Antara online dengan tatap muka, (3) Media pembelajaran, (4) Teori pembelajaran, (5) Tujuan pembelajaran, (6) Ilmu pendidikan (Mariani 2020, 1).

Dalam penelitian ini akan mempelajari dan meneliti sejauh mana Youtube dapat digunakan sebagai media pembelajaran di masa pandemi ini. Youtube dapat digunakan sebagai media pembelajaran sekaligus sumber belajar dan sudah sangat akrab terhadap peserta didik di era ini. Youtube begitu populer, terlebih dikalangan masyarakat Indonesia berdasarkan survei We are Social mengatakan 150 juta penduduk menggunakan media sosial salah satunya Youtube menjadi platform terbanyak yang diakses yaitu 88\% dari total pengguna pada tahun 2019 oleh penduduk Indonesia. Penelitian ini berdasarkan pada pembelajaran mata pelajaran bahasa Arab kelas XI di SMAIT Al Huda Wonogiri di masa pandemi. Hasil penelitian ini diharapkan bisa bermanfaat, sebagai acuan pembelajaran berbasis internet di masa pandemi ini, khususnya pada mata pelajaran bahasa Arab dan mata pelajaran lainnya.

\section{METODE PENELITIAN}

Penelitian ini berdasarkan kegiatan pembelajaran bahasa Arab kelas XI di SMAIT Al Huda Wonogiri dengan menggunakan Youtube sebagai solusi media pembelajaran di masa pandemi. Melihat mata pelajaran Bahasa Arab ini tidak hanya mengedepankan teori saja melainkan 4 keterampilan berbahasa yang harus dikuasai peserta didik, adapun 4 ketrampilan ini adalah keterampilan mendengar (maharatul istima), membaca (qira'ah), berbicara (kalam), dan menulis (kitabah). Sehingga membutuhkan media pembelajaran yang tepat untuk memudahkan peserta didik dalam pembelajaran bahasa Arab di masa pandemi, pembelajaran yang tidak membebankan peserta didik selama belajar dari rumah dengan sistem PJJ. 
Terdapat 96 peserta didik kelas XI di SMAIT Al Huda Wonogiri terbagi menjadi 4 kelas dengan rincian XI MIPA 1 berjumlah 29 peserta didik, XI MIPA 2 berjumlah 18 peserta didik, XI IPS 1 berjumlah 28 dan XI IPS 2 berjumlah 21 dengan total keseluruhan 96 peserta didik. Penelitian deskriptif kualitatif adalah yang digunakan dalam penelitian ini, sehingga dapat menjelaskan berbagai keadaan, atau variabel yang ada dari suatu komunitas atau subjek penelitian. Setelah itu mengambil kesimpulan sebagai ciri atau kekhasan tentang kondisi, situasi ataupun variabel tertentu. Dengan demikian penelitian deskriptif kualitatif adalah metode yang tepat dengan tujuan penelitian ini.

Sementara format deskriptif dalam penelitian ini menggunakan format deskriptif survei (syakl al-dirasah al-mashiyyah) (Musthafa and Hermawan 2017, 86). Pengumpulan data dari penelitian ini menggunakan kuesioner (al-istibyan) link dengan skala likert melalui google form, kemudian dibagikan kepada peserta didik dengan 11 pertanyaan terkait penelitian Youtube sebagai solusi media pembelajaran di masa pandemi dengan sistem pembelajaran PJJ. Penelitian survei (al-bahs al mashi) bertujuan untuk mengumpulkan informasi tentang orang yang berjumlah tidak sedikit, dengan cara mewawancarai sejumlah kecil dari populasi tersebut. Untuk mendapatkan keterangan yang dianggap representatif, dapat menggunakan kuesioner (al-istibyan), wawancara (al-muqabalah), observasi (al-mulahazah) langsung atau kombinasi teknik-teknik pengumpulan data. Dan dalam penelitian ini menggunakan kuesioner (al-istibyan) untuk memperoleh data survei yang akan diambil dari sejumlah kecil dari peserta didik di setiap kelasnya secara random atau acak dengan memperhatikan jumlah sampel dan juga observasi (al-mulahazah), sehingga sampel dapat digeneralisasikan pada populasi, kemudian data dapat diuji kebenaran asumsi atau hipotesis tertentu.

Patton mengatakan dalam Moleong 2019 bahwa tujuan dari observasi yaitu untuk menjelaskan secara detail dari apa yang dipelajari, kegiatan yang berlangsung, serta orang-orang yang terkait dalam aktivitas, dan makna kejadian dilihat dari perspektif mereka yang terlihat dalam kejadian yang diamati oleh peneliti (Moleong 2019, 176). Jenis yang dapat dilakukan oleh peneliti untuk observasi penelitian diantaranya yaitu: (1) Observasi partisipatif, (2) Observasi terus-terang atau tersamar, (3) Observasi tak terstruktur. Dalam penelitian ini menggunakan Observasi tak 
terstruktur yaitu dilaksanakan secara tidak terstruktur dan multidimensi sehingga tidak perlu menggunakan penjadwalan. Peneliti melakukan penjajakan dan eksplorasi ke lokasi penelitian dan mencari serta memperhatikan apa yang ada serta gejala yang tampak tanpa sistematika dan persiapan yang terstruktur (Afifuddin dan Saebani 2018).

Menurut Bogdan \& Biklen (1982) dalam Moleong 2019, Konsep analisis data kualitatif adalah sebuah usaha dengan cara bekerja melalui data, pengelompokan data, memfilter data, mencari dan mendapatkan pola, mendapatkan kesimpulan penting dari apa yang dipelajari, dan menentukan bagian yang akan dipublikasikan (Moleong 2019, 248). Aktivitas dalam analisis data menurut Miles \& Huberman (1984), yaitu; (1) Reduksi data (data reduction), (2) Penyajian data (data display), dan (3) Kesimpulan (conclusion drawing/verification) (Sugiyono 2020, 35). Adapun dalam penelitian ini menggunakan analisis menurut Miles \& Huberman.

\section{HASIL DAN PEMBAHASAN}

\section{Pembelajaran di Masa Pandemi}

Kegiatan pembelajaran di masa pandemi menempuh berbagai polemik, setelah terbitnya Surat Edaran no. 4 tahun 2020 dari Menteri Pendidikan dan kebudayaan yang menerangkan pembelajaran di masa pandemi. Hingga kebijakan SKB Empat Menteri yang menegaskan bahwa pembelajaran tatap muka diperbolehkan, tetapi tidak diwajibkan serta harus mendapat izin dari Pemda setempat. Adapun kegiatan pembelajaran di kelas XI SMAIT Al Huda Wonogiri dilaksanakan dengan Pembelajaran Jarak Jauh (PJJ).

Pengertian dari pembelajaran itu sendiri, Kimble dan Garmezy dalam Erni Ivanti 2017 berpendapat bahwa suatu perubahan tingkah laku yang relatif tetap merupakan hasil praktik yang dilakukan secara kontinyu atau terus menerus, Rombepajung juga berpendapat bahwa pembelajaran merupakan perolehan dari suatu mata pelajaran atau perolehan dari suatu keterampilan yang melalui pelajaran, pengalaman, atau dari suatu pengajaran (Erni Ivianti 2017, 26). Dengan adanya pembelajaran peserta didik diharapkan mampu mempraktekkannya dalam kehidupan sehari-hari pada lingkup kecil keluarga atau dalam lingkup luas yaitu dengan masyarakat. 
Pembelajaran bahasa Arab di Madrasah Aliyah atau Sekolah Menengah Atas Islam memiliki tujuan yaitu ketercapaiannya kemampuan peserta didik untuk memahami dan mempraktekkan bahasa Arab dengan lancar di kehidupan sehari-hari (Dahlan 2003, 8). Tujuan ini adalah acuan bagi pendidik, supaya mampu menguasai materi pembelajaran yang akan diajarkan menggunakan metode dan media pembelajaran yang tepat. Terlebih di masa pandemi ini pembelajaran dilaksanakan dengan sistem pembelajaran jarak jauh, harus ada upaya extra untuk membuat aktivitas kegiatan pembelajaran yang menarik, supaya materi ajar tersampaikan secara maksimal.

Di era teknologi digital ini banyak sekali platform yang ditawarkan untuk keberlangsungan kegiatan pembelajaran di masa pandemi ini seperti Google Classroom, rumah belajar, Zoom, Video Conference, Live Chat, MS Teams dan lainnya. Sementara di SMAIT Al Huda Wonogiri kegiatan pembelajarannya dilaksanakan melalui ruang kelas online dengan MS Teams atau Microsoft Teams adalah platform komunikasi yang menyatukan orang untuk percakapan, konten, serta alat yang diperlukan suatu komunitas supaya dapat berkolaborasi dengan mudah tidak terbatas ruang dan waktu. Microsoft Teams terintegrasi dengan aplikasi Office 365, dan sudah ditinjau di 181 negara dalam 18 bahasa (Koenigsbauer 2016). Dengan menggunakan MS Teams ini, pendidik dapat melakukan pengembangan dalam membuat kegiatan pembelajaran diantaranya dengan menggunakan media youtube, mentimeter , dan permainan kuis interaktif dengan menggunakan Quizizz, dst. Titik pembahasan dalam penelitian ini adalah media pembelajaran menggunakan Youtube di masa pandemi.

Dalam situasi pembelajaran dengan sistem PJJ pendidik dituntut untuk kreatif dan inovatif dalam melaksanakan kegiatan tersebut salah satunya yaitu dengan membuat media pembelajaran yang terbaru atau up to, agar kegiatan pembelajaran tidak membosankan, sehingga peserta didik selalu termotivasi untuk semangat belajar. Sementara itu untuk pengertian PJJ itu sendiri Kementrian Pendidikan dan Kebudayaan (Kemendikbud) memaparkan bahwa sistem Pembelajaran Jarak Jauh (PJJ) memiliki perbedaan dengan pembelajaran secara daring (online) dan luring (offline) (Pramana 2020). PJJ merupakan adopsi dari pembelajaran daring, pendidik dituntut kreatif dalam memberikan materi. Menurut Dogmen ciri-ciri Pembelajaran Jarak Jauh adalah adanya organisasi yang mengatur cara belajar mandiri, materi 
pembelajaran disampaikan melalui media, dan tidak ada kontak langsung antara pendidik dan peserta didik.

Dalam penelitian ini meneliti media pembelajaran dengan menggunakan media Youtube, untuk pengambilan data menggunakan random sampel dari setiap kelas XI di SMAIT Al Huda Wonogiri dengan rincian: XI IPS 1 berjumlah 10 peserta didik, XI IPS 2 berjumlah 6 peserta didik, XI MIPA 1 berjumlah 10 peserta didik, dan XI MIPA 2 berjumlah 7 peserta didik. Total keseluruhan berjumlah 33 peserta didik yang mengisi kuesioner, peserta didik dipilih secara acak. Pada pemaparan ini diambil dari pertanyaan pokok yang mewakili dari 11 pertanyaan yang terdapat dalam kuesioner, Dengan hasil penelitian sebagai berikut:

Gambar 1. Pendapat pembelajaran bahasa Arab kesulitan saat PJJ

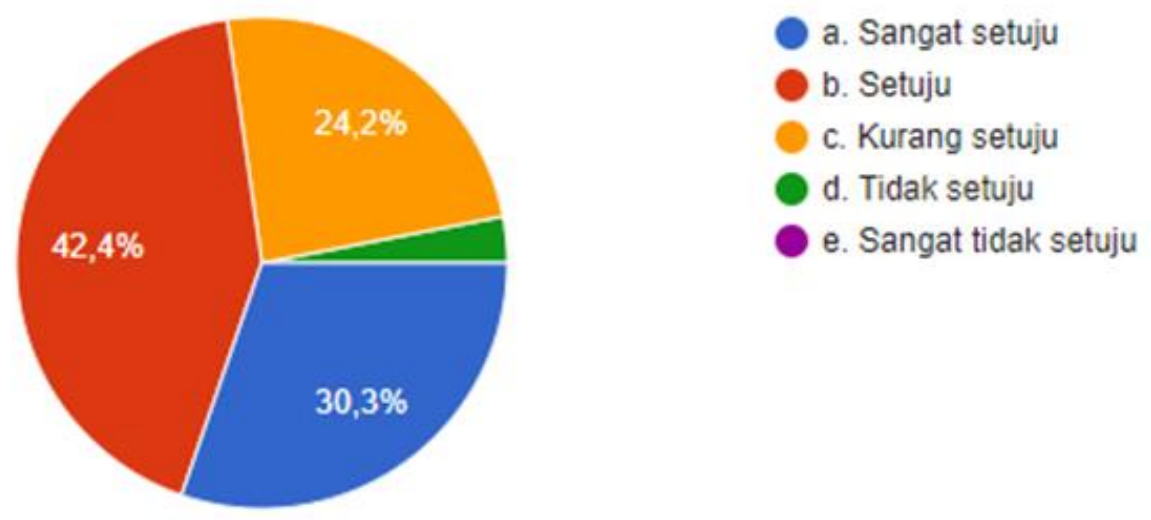

Berdasarkan gambar diatas, diketahui bahwa responden memiliki variasi jawaban. Gambar 1, menjelaskan bahwa sebanyak 14 (42,4\%) peserta didik setuju bahwa pembelajaran bahasa Arab dengan sistem PJJ di masa pandemi ini mengalami kesulitan. Peserta didik yang sangat setuju sebanyak 10 (30,3\%) peserta didik, dan yang merasa kurang setuju sebanyak $8(24,2 \%)$ peserta didik dan hanya 1 anak yang tidak setuju. Dilihat dari hasil keseluruhan peserta didik merasa pembelajaran Bahasa Arab dengan sistem PJJ di masa pandemi ini mengalami kesulitan. Dan 24,2\% yang merasa kurang setuju melihat dari hasil ini masih ada beberapa peserta didik yang menyukai pembelajaran dengan sistem PJJ, semenatara hanya 1 peserta didik yang merasa tidak setuju jika pembelajaran bahasa Arab di masa pandemi dengan PJJ itu sulit. Dengan hasil akhir menggunakan perhitungan Skala Likert yaitu $80 \%$, yang menunjukkan peserta didik sangat setuju jika pembelajaran bahasa Arab di masa pandemi mengalami kesulitan. 
Kesulitan yang peserta didik alami memiliki banyak faktor diantaranya: (1) bahasa Arab adalah bahasa asing, (2) minimnya bank kata bahasa Arab peserta didik, atau mufradat yang berarti kosakata (3) akses internet yang terkadang tidak stabil (4) belum terbiasa menggunakan font Arab dalam pengetikan maupun penulisan. Namun bagaimana dengan suasana pembelajaran bahasa Arab di masa pandemi dengan sistem PJ]? Hasil penelitian sebagai berikut:
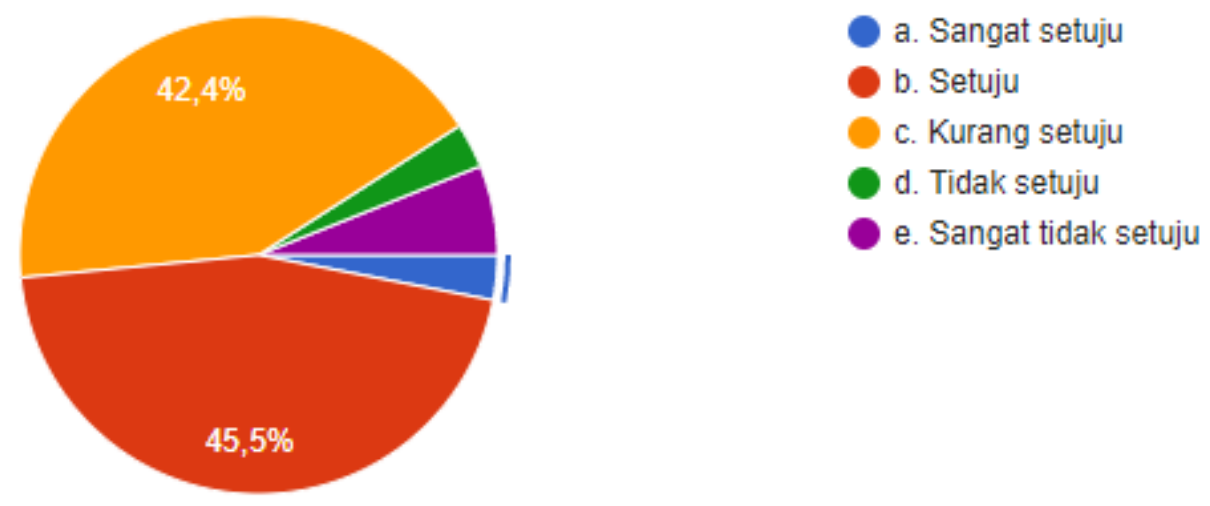

Gambar 2. Pembelajaran bahasa Arab menyenangkan dengan sistem PJJ

Meski merasa kesulitan dengan Pembelajaran Jarak Jauh untuk mata pelajaran bahasa Arab di masa pandemi. Namun masih banyak dari peserta didik kelas XI SMAIT Al Huda Wonogiri yang merasa senang dalam pembelajaran bahasa Arab dengan sistem PJJ selama masa pandemi ini, dengan dibuktikan melalui hasil penelitian. Yang menunjukan bahwa sebanyak 15 peserta didik (45,5\%) setuju, 14 peserta didik $(42,2 \%)$ peserta didik kurang setuju, sementara 2 peserta didik sangat tidak setuju, 1 peserta didik tidak setuju. Dengan perhitungan akhir yaitu 67\% peserta didik menyatakan setuju, bahwa pembelajaran bahasa Arab dengan sistem PJj selama masa pandemi ini menyenangkan.

\section{Persepsi Peserta Didik Youtube sebagai Media Pembelajaran}

Perkembangan teknologi yang sangat cepat, terutama teknologi informasi dan komunikasi menjadi kebutuhan pokok dalam kehidupan manusia sehari-hari, dimanapun dan kapanpun tidak lepas dari alat komunikasi yang menggunakan jaringan internet. Dan juga dapat dimanfaatkan sebagai salah satu media pembelajaran, yakni sarana yang menjembatani hubungan antara peserta didik dan sumber belajar baik dari pendidik maupun sumber belajar lainnya. Seperti halnya yang diungkapkan oleh Suryani, dkk. (2018:4) mengemukakan bahwa media pembelajaran 
adalah media yang digunakan dalam pembelajaran, yang meliputi alat bantu pendidik dalam mengajar dan juga menjadi saran pesan dari sumber belajar ke peserta didik.

Salah satu wujud dari perkembangan teknologi ini adalah dengan adanya Youtube layanan video yang disediakan oleh Google bagi para penggunanya secara gratis. Pertumbuhan Youtube terus meningkat setiap bulannya lebih dari 2 miliar pengguna login membuka Youtube dan setiap hari dari satu miliar jam video dan menghasilkan miliaran kali penayangan. Dan lebih dari 70\% waktu tonton berasal dari perangkat seluler (YouTube 2021). Betapa Youtube sangat berpengaruh dan familiar di kalangan manusia terlebih anak muda yang sangat melek dengan teknologi terlebih teknologi komunikasi, dengan demikian menjadikannya Youtube sebagai media pembelajaran berpeluang besar sebagai solusi media pembelajaran di masa pandemi ini. Terlebih peserta didik kelas XI SMAIT Al Huda Wonogiri yang keseluruhan sudah memiliki gawai, tentu bukanlah hal yang sulit jika menggunakan media pembelajaran Youtubesebagai solusi media pembelajaran di masa pandemi. Dibuktikan dengan hasil penelitian sebagai berikut:

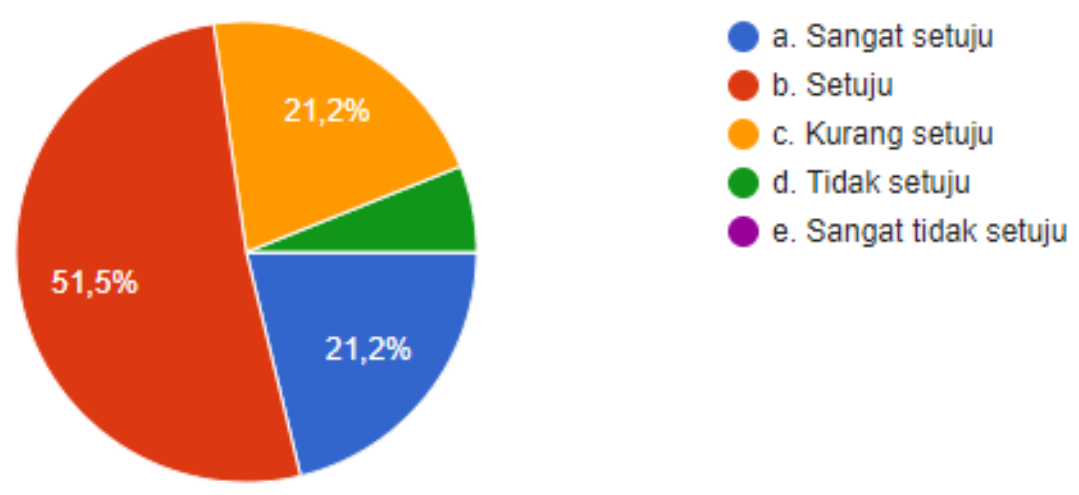

Gambar 3. Media Youtube lebih memudahkan pembelajaran bahasa Arab di masa Pandemi

Berdasarkan gambar 3, diketahui bahwa responden memiliki variasi jawaban. Gambar 3 menjelaskan bahwa 17 (51,5\%) peserta didik setuju bahwa pembelajaran menggunakan media Youtube lebih mudah dipahami di masa pandemi ini. Dan sebanyak $7(21,2 \%)$ peserta didik sangat setuju, sementara yang kurang setuju terdapat $7(21,2 \%)$ peserta didik, dan 2 peserta didik yang tidak setuju jika media pembelajaran melalui Youtube memahamkan. Dengan hasil akhir menggunakan 
perhitungan skala likert yaitu $79 \%$, dilihat dari hasil akhir survei ini membuktikan bahwa media pembelajaran Youtube memahamkan peserta didik kelas XI SMAIT Al Huda Wonogiri di masa pandemi, karena lebih dari setengah responden menyatakan setuju dibandingkan dengan yang tidak setuju hanya beberapa peserta didik.

Pemahaman dalam mata pelajaran bahasa Arab mencakup 4 keterampilan (1) Keterampilan mendengarkan, keterampilan ini adalah dasarnya karena mendengar adalah sarana pertama yang digunakan manusia untuk berhubungan dengan sesamanya, (2) Keterampilan berbicara, setelah mendengar banyak dari perkataan Bahasa Arab maka sudah mampu untuk memulai berbicara, dalam bentuk kalimat dan pada akhirnya membentuk ungkapan yang dapat memahami lawan bicaranya, (3) Keterampilan membaca, yaitu ketrampilan pada tahap ketiga seseorang akan merasa kesulitan membaca jika sebelumnya belum pernah mendengar dan berbicara, (4) Keterampilan menulis, adalah ketrampilan terakhir yang bertujuan dapat menulis bahasa Arab yang benar sesuai dengan kaidah bahasa Arab dan dapat memberi masukan kepada pembaca atau pembelajar Bahasa Arab itu sendiri. Dan apakah media Youtube adalah solusi tepat sebagai media pembelajaran bahasa Arab di masa pandemi dengan sistem PJJ? Perhatikan hasil survei berikut:

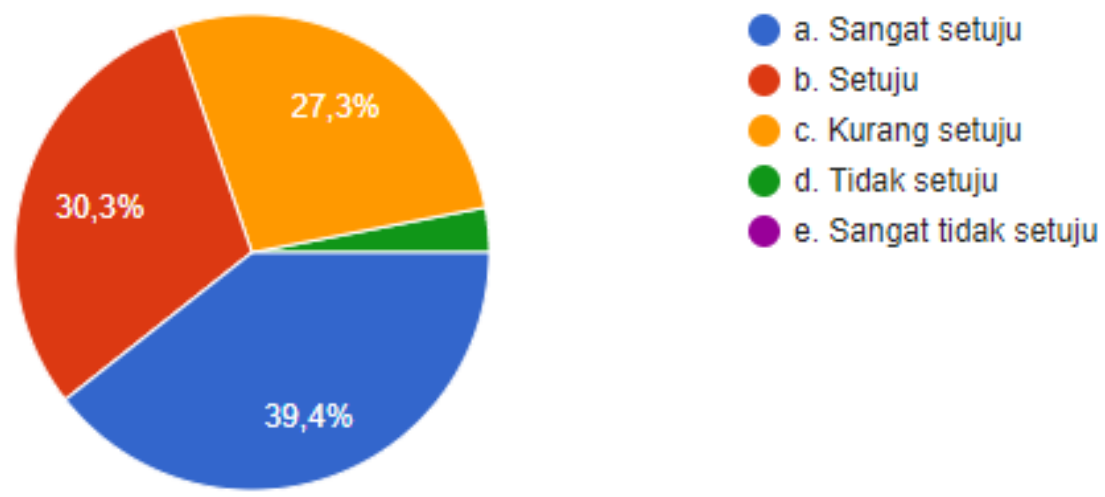

Gambar 4. Media Youtube solusi tepat untuk menerangkan materi bahasa Arab saat PJJ

Berdasarkan gambar 4, diketahui bahwa responden memiliki variasi jawaban. Gambar 4. Menjelaskan bahwa 13 (39,4\%) peserta didik sangat setuju bahwa Youtube adalah solusi tepat untuk media pembelajaran bahasa Arab saat PJJ di masa pandemi. $10(30,3 \%)$ peserta didik setuju, sementara $9(27,3 \%)$ peserta didik yang kurang setuju dan 1 peserta didik menyatakan tidak setuju. Dengan hasil akhir menggunakan perhitungan skala likert yaitu $84 \%$ dengan interpretasi sangat setuju. Dilihat dari hasil 
keseluruhan media pembelajaran menggunakan Youtube bernilai positif. Sehingga dinyatakan Youtube adalah solusi tepat untuk media pembelajaran dengan sistem PJJ pada mata pelajaran bahasa Arab di masa pandemi.

Dalam pembelajaran bahasa Arab menggunakan media Youtube mampu melatih beberapa keterampilan bahasa peserta didik, terlebih keterampilan mendengar, contoh materi yang disajikan dengan Film kartun menggunakan penutur asli serta terdapat terjemahan Bahasa Indonesia dalam video tersebut. Peserta didik tidak merasa bosan karena Youtube termasuk Audio Visual, yaitu media yang melibatkan suara dan gambar, memiliki kemampuan yang lebih baik jika digunakan sebagai media pembelajaran, karena meliputi 2 jenis media auditif (mendengar) serta visual (melihat). Media pembelajaran menjadi menyenangkan dan tidak terkesan membosankan. Pemahaman ini dikuatkan dengan adanya penelitian video ceramah bahasa Arab menggunakan penutur asli pada mahasiswa Pendidikan Bahasa Arab Universitas Negeri Jakarta, dengan hasil 91,3\% sebanyak 31 responden setuju bahwa video ceramah penutur asli mampu memotivasi mahasiswa untuk belajar bahasa Arab (Wahhab 2020). Persamaan dalam penelitian ini yaitu menggunakan video sebagai media pembelajaran bahasa Arab.

Salah satu tujuan pembelajaran menggunakan Youtube seperti yang dipaparkan Sukarni (2012) yaitu membentuk situasi pembelajaran yang menarik, menyenangkan dan interaktif. Dan beberapa keunggulan Youtube sebagai media pembelajaran yaitu: (1) Youtube memiliki potensi karena sebagai situs populer di dunia internet, (2) Praktis, mudah digunakan dan semua kalangan bisa mengakses terutama peserta didik dan pendidik, (3) Informatif, memberikan perkembangan informasi dari berbagai ilmu pendidikan, teknologi, kebudayaan, dll, (4) Interaktif, memberikan ruang untuk para pengguna berdiskusi atau bahkan mereview sebuah video pembelajaran, (5) Shareable, mudah disebarluaskan dengan link HTML, Embed yang dapat disebarkan melalui jejaringan sosial seperti Facebook, Twitter dan juga blog/website, (6) ramah di kantong, tidak berbayar untuk pengguna (Seminar and Etnomatnesia 2014, 810).

\section{Kelebihan dan Kekurangan Youtube sebagai Media Pembelajaran}

Dalam setiap media pembelajaran, terdapat kelebihan dan kekurangan bukanlah suatu hal yang mengherankan. Justru akan feedback perkembangan media 
itu sendiri. Akses menuju Youtube sangatlah mudah jika sudah terhubung dengan jaringan internet, dapat dijangkau melalui komputer, laptop, ataupun dengan gawai lainnya. Adapun kekurangannya adalah terdapat video yang tidak pantas dilihat atau ditonton oleh khalayak umum. Dan juga terdapat kemungkinan ujaran kebencian di dalam komentar (Mahendra 2020, 3). Tidak hanya ujaran kebencian banyak juga spam - spam yang tidak pantas yang dikirimkan di kolom komentar oleh pengguna yang tidak bertanggung jawab. Sehingga pemanfaatan media Youtube ini peserta didik juga diberikan arahan dan edukasi bagaimana bersikap dan menghadapi hal-hal buruk dalam Youtube itu sendiri.

Jika meninjau kelebihan dan kekurangan Youtube sebagai media pembelajaran bahasa Arab dengan sistem PJJ saat masa pandemi di kelas XI SMAIT Al Huda Wonogiri, diantara kekurangannya yaitu: (1) Beberapa peserta didik terkendala sinyal dan kuota, sehingga di video pembelajaran ditonton di luar jam KBM (Kegiatan Belajar Mengajar), (2) Tidak bisa memastikan apakah peserta didik telah memperhatikan video pembelajaran dari awal hingga akhir, (3) Beberapa peserta didik melompati video pembelajaran dan langsung mengerjakan latihan soal terkait materi dalam video, dst. Adapun kelebihan dari pembelajaran bahasa Arab menggunakan media Youtube diantaranya: (1) Bisa ditonton berulang kali, (2) Bisa disimpan secara offline atau download dalam memori gawai, (3) Menarik untuk ditonton karena materi pembelajaran divisualisasikan dalam bentuk gambar bergerak dan suara, (4) Sekaligus melatih maharah istima peserta didik, (5) Peserta didik lebih semangat jika video pembelajaran dibuat oleh pendidiknya langsung, dst.

\section{KESIMPULAN DAN SARAN}

Pembelajaran bahasa Arab di masa pandemi tidaklah mudah bagi peserta didik di kelas XI SMAIT Al Huda Wonogiri terlihat dari data persentase total (67\%) peserta didik setuju bahwa pembelajaran bahasa Arab dengan sistem Pembelajaran Jarak Jauh di masa pandemi ini mengalami kesulitan. Salah satu faktor utamanya adalah bahasa Arab bukanlah bahasa Ibu dan belum adanya lingkungan berbahasa Arab dalam kesehariannya. 
Media pembelajaran Youtube, sebagai solusi yang tepat untuk pembelajaran bahasa Arab selama PJJ di masa pandemi pada kelas XI SMAIT AI Huda Wonogiri adalah solusi yang tepat, karena menjelaskan pembelajaran melalui Youtube bisa diakses kapan saja dan dimana saja selain itu juga bisa disimpan secara offline. Dan keseluruhan peserta didik sudah memiliki gawai untuk sarana belajar selama PJj ini. Dibuktikan dengan adanya persentase survei terdapat total akhir (84\%) peserta didik sangat setuju sehingga menunjukkan hasil yang positif bahwa Youtube adalah solusi tepat untuk media pembelajaran bahasa Arab saat PJJ di masa pandemi.

Berdasarkan hasil penelitian ini, disarankan agar kepala sekolah, pendidik, karyawan, peserta didik, dst. Membiasakan atau mengadakan suatu program khusus untuk menciptakan lingkungan berbahasa terutama bahasa Arab secara daring maupun luring, sehingga peserta didik akan mudah terlatih dalam pembelajaran berbahasa Arab. Sehingga termotivasi untuk meningkatkan semangat belajar peserta didik.

\section{REFERENSI}

Afifuddin, and Beni Ahmad Saebani. 2018. Metodologi Penelitian Kualitatif. 3rd ed. Bandung: Cv. Pustaka Setia.

Baihaqi, Achmad, Amaliya Mufarroha, and A Ilham Tsabit Imani. 2020. "Edusiana: Jurnal Manajemen Dan Pendidikan Islam Youtube Sebagai Media Pembelajaran Pendidikan." Jurnal Manajemen Dan Pendidikan Islam 07, no. 01: 74-88. Dahlan, Juwariyah. 2003. Paradigma Baru Dalam Pembelajaran Bahasa Arab (Kajian Teoritis Dan Praktis). jogjakarta: Sumbangsih.

Dewi, Putra Kumala, and Nia Budiana. 2018. Media Pembelajaran Bahasa: Aplikasi Teori Belajar Dan Strategi Pengoptimalan Pembelajaran. Universitas Brawijaya Press.

Erni Ivianti, Slameto. 2017. "Meningkatkan Hasil Belajar Siswa Dengan

Menggunakan Metode Project Based Learning." Jurnal Handayani 7: 92-99. /jurnal.unimed.ac.id.

Harsanto, Budi. 2017. Inovasi Pembelajaran Di Era Digital: Menggunakan Google Sites Dan Media Sosial. Unpad Press. 
Koenigsbauer, Kirk. 2016. "Memperkenalkan Microsoft Teams, Ruang Kerja Berbasis Obrolan Di Office 365." Microsoft, November 2016.

https://www.microsoft.com/id-id/microsoft-365/blog/2016/11/02/introducingmicrosoft-teams-the-chat-based-workspace-in-office-365/.

Lestari, Renda. 2013. "Penggunaan Youtube Sebagai Media Pembelajaran Bahasa Inggris." Seminar Nasional Kedua Pendidikan Berkemajuan Dan Menggembirakan (The Second Progressive and Fun Education Seminar), 60712.

https://publikasiilmiah.ums.ac.id/bitstream/handle/11617/9566/68.pdf?sequenc $\mathrm{e}=1$ \&isAllowed $=\mathrm{y}$.

Mahendra, Mochamad. 2020. "Youtube Sebagai Media Pembelajaran." ResearchGate, 3.

Mariani, Adelina. 2020. "Implementasi Perkuliahan Secara Blended Learning Dalam Peningkatan Kualitas Pembelajaran."

Moleong, Lexy J. 2019. Metodologi Penelitian Kualitatif. Edisi Revi. Bandung: Pt Remaja Rosdakarya.

Musthafa, Izzudin, and Acep Hermawan. 2017. Metodologi Penelitian Bahasa Arab.

Edited by Kuswandi. E. 1st ed. Bandung: Pt Remaja Rosdakarya.

Pramana, Edy. 2020. "Kemendikbud Sebut PJ] Tak Sama Dengan Pembelajaran Daring Dan Luring." JawaPos.Com, June 17, 2020.

Sadiman dkk. 2006. Media Pendidikan. Edited by Raja Persada Grafindo. jakarta:

Rajawali Press.

Seminar, Prosiding, and Nasional Etnomatnesia. 2014. "DEWANTARA UNTUK MATERI INTEGRAL DI SMA 1 ) Program Studi Pendidikan Matematika FKIP UST Jl . Batikan 2 Yogyakarta , Indonesia , e-Mail : Sofyani.Wigati20@gmail.Com 2 ) Program Studi Pendidikan Matematika FKIP UST JI . Batikan 2 Yogyakarta, Indonesia , Em," 810-13.

Sugiyono. 2020. Metode Penelitian Kualitatif. 3rd ed. Bandung: Penerbit Alfabeta. Susanto, Heri, and Helmi Akmal. 2019. Media Pembelajaran Sejarah Era Teknologi Informasi: Konsep Dasar, Prinsip Aplikatif, Dan Perancangannya. Media Pembelajaran. http://eprints.ulm.ac.id/8313/1/10. Media Pembelajaran Sejarah Era Teknologi Informasi.pdf. 
Wahhab, Abdul. 2020. "'Trends and Future Perspectives on Arabic Education, Linguistics, Literature, Culture, and Translation' 12/17/ 2020," 123-28. Wulandari, Kartika Yulianti. 2017. "Kartika Yulianti Wulandari, 2017 Penggunaan Media Youtube Dalam Pembelajaran Menyimak Bahasa Perancis Universitas Pendidikan Indonesia | Repository.Upi.Edu | Perpustakaan.Upi.Edu." YouTube, About. 2021. "Jangkauan Global Youtube." Pers YouTube, 2021. 